\title{
Status and Performance of University Librarians in Uganda
}

\author{
Robinah Kalemeera Namuleme ${ }^{1}$ \\ ${ }^{1}$ Nkumba University [E-mail: namulemerobinah@gmail.com ]
}

\begin{abstract}
The thesis of this study is that the status of the university librarian is of significant value to his/ her performance. This study set out to ascertain this significance by investigating the status and performance of librarians in selected universities in Uganda. The findings were that the status of the university librarians in the country is only fairly satisfactory. It was also found that the status of university librarians is a significant predictor of their performance. Therefore, the paper urges university administrators in the country to re-examine the status accorded to their librarians because it is an important ingredient in their performance.
\end{abstract}

Keywords: Library management; Performance management; Human resources development.

\section{$1 \quad$ Introduction}

According to Robbins (1991) status is a socially defined position or rank given to groups or group members by a group. Buchanan and Huczynki (1985) define formal status as a collection of rights and obligations associated with a position, as distinct from the person who may occupy it. Robbins (1991) points out that status may be formal or informal. Informal status is one imposed by a group. Formal status goes with high organizational status for example large offices with impressive views, high pay and similar things. Status may also be informally acquired by such characteristics as education, age, gender, skill and experience.

The formal status hierarchy reflects the potential of the holder of a position to contribute to the overall goals of the organization (Buchanan 1985: 312-321). The outward symbols associated with formal status inform other members in the organization where exactly that person stands on 'the ladder'. 
In the context of a university, librarians are partners with academic staff in contributing to the scholarly and intellectual functions of universities. They are skilled professionals who play an integral role in the pursuit, dissemination and structuring of knowledge in the university environment. As such the status of the Librarian should be a matter of concern. However, hitherto, the status of university librarians in Uganda and its effect on the performance of their universities has not attracted scholarly attention. To close this gap, this study was conducted to examine the status of librarians in universities in Uganda and to establish the effect of this status on the librarians' performance. It was hypothesized that the status of the librarian significantly affects his/her performance.

\section{$2 \quad$ Related Literature}

Although literature on the status of university librarians in Uganda is scanty, there are some other studies that have been made on this subject, especially in foreign contexts. Status is an important factor in understanding human behaviour, because it is a significant motivator and has major consequences when individuals perceive a disparity between what they believe their status to be and what other perceive. While Status congruence refers to a situation where the responsibility of a job that a person had is congruent with his superiority Robbins (1991) emphasized the importance of status equity. He pointed out that when inequity is perceived, disequilibrium is created. He pointed out that, it is important to pay attention to trappings that go with formal positions in order to maintain equity. He stressed that when there is an inequity between the perceived ranking of an individual and the status accoutrements that person is given by an organization, status incongruence is said to exist. Examples of this kind of incongruence are; a more desirable office for a lower ranking individual, a vehicle or fuel refund for a lower ranking individual and not for an officer in a higher office.

The equity theory is concerned with perceptions people have about how they are being treated as compared with others. To be dealt with equitably is to be treated fairly in comparison with another group of people (a reference group) or a relevant other person (Armstrong 1996: 308).

Equity theory states that people will be better motivated if they are treated equitably and demotivated if they are treated inequitably. A study conducted by Adams (1953) on the US Army Bomber crews revealed that status congruence affected efficiency. The study revealed that low status congruence was found to reduce efficiency of Bomber crews. On the other hand where a moderate degree of congruency existed, the Bomber crews performed better as measured by the number of targets hit during bombing practice. The point there is that 
employees expect the rights and obligations individuals have to be congruent with their status.

It has been asserted that participating in management (D'Elia 1979: 283302,) having the decision making power (Rockman 1985: 45-63) independence on the job D'Elia 1979: 283-302) have a positive impact on the workers status and hence performance. D'Elia (1979: 283-302) pointed that factors related to the job itself such as using talents, creativity, responsibility, recognition have influence on the workers' status.

Armstrong (1996) points out that motivation and commitment are likely to be enhanced if employers feel that they are valued. This means investing in their success, trusting and empowering them, giving them the opportunity to be involved in matters with which they are concerned, keeping them fully in the picture, treating them fully like human beings rather than resources to be exploited in the interest of management and providing them rewards (financial and no-financial) which demonstrate the extent to which they are valued. This suggests the need to trust people and treat them like adults, enthuse them by lively and imaginative leadership, develop and demonstrate an obsession for equity; make them feel they own the business. Together these will help the workforce to respond with total commitment. These studies addressing work life issues combined with those focused exclusively on organizational outcomes suggest the theoretical and practical value of research on the effect of status on performance.

\section{$3 \quad$ Methodology}

Data was collected from a purposive sample of Vice Chancellors, Deputy Vice Chancellors, Academic Registrars, University Secretaries, Deans, Deans of Students, Librarians and University Librarians. A total of 23 university administrators and academics and one respondent from the National Library of Uganda participated in the study. Thirteen (13) of the respondents were male. Data was collected using a 54-item questionnaire augmented by unstructured observation and key informant interviews. The major status indicators on which the respondents' opinions were elicited included level of control, participation in governance and policy making, level participation in decision making; level of participation in human resource planning, development and management; rating of the librarian in relation to other university officers and the importance attached to library staff development. The data collected were analysed using descriptive statistics and Pearson's correlation-coefficient. 


\section{$4 \quad$ Findings and Discussion}

The findings on the status and performance of university librarians are summarized in Table 1.

Table 1: Status and Participation of University Librarian in University Affairs

\begin{tabular}{|c|c|c|c|}
\hline Variable & Attributes & Mean & SD \\
\hline Human & The status of the Librarian is satisfactory & 3.46 & 1.103 \\
\hline Resource & The Librarian is responsible for interviewing, hiring and dismissing library staff & 3.04 & 1.331 \\
\hline \multirow[t]{6}{*}{ Management } & The Librarian communicates optimum staffing level requirements to the administration & 4.08 & .929 \\
\hline & The Librarian supervises the work of all library staff & 4.46 & .884 \\
\hline & The Librarian works for improvements in working conditions, salary scale and benefits & 3.88 & 1.191 \\
\hline & The Librarian supports staff members in professional development & 4.17 & 1.029 \\
\hline & The Librarian is highly regarded by staff & 4.25 & 1.073 \\
\hline & The Librarian is highly regarded by the administration & 4.22 & .998 \\
\hline Financial & The Librarian is a signatory to the library account & 4.21 & 1.215 \\
\hline \multirow[t]{4}{*}{ Management } & The Librarian seeks to improve library service and collections in a fiscal way & 4.25 & .989 \\
\hline & The Librarian prepares preliminary budget in consultation with staff members & 4.04 & 1.083 \\
\hline & The Librarian purses additional support for the library at local and international level & 4.04 & 1.147 \\
\hline & The role of the Librarian in financial matters is adequate & 3.83 & .868 \\
\hline \multirow{10}{*}{$\begin{array}{l}\text { Governance } \\
\text { and Policy } \\
\text { Making }\end{array}$} & The Librarian recommends, plans and implements library services & 4.29 & .999 \\
\hline & The Librarian recommends necessary changes in services to keep current with user needs & 4.46 & .932 \\
\hline & The Librarian provides assists university administration in long and short term planning & 4.13 & .947 \\
\hline & The Librarian evaluates effectiveness of the library in relation to the user community & 4.17 & 1.049 \\
\hline & The Librarian recommends and administers procurement policies of the library & 4.21 & 1.141 \\
\hline & The librarian prepares regular reports on current progress and future needs & 4.21 & .977 \\
\hline & The Librarian co-operates with other libraries to make effective use of funds & 4.00 & .885 \\
\hline & Takes responsibility for collection development and acquisitions including weeding & 6.22 & 10.68 \\
\hline & The Librarian keeps informed of relevant academic and technological developments & 4.17 & 1.007 \\
\hline & The Librarian attends meetings that are relevant to the effective functioning of the library & 4.37 & .970 \\
\hline
\end{tabular}


The Librarian is a key policy maker in a university library

The Librarian knows national, regional and international laws that affect libraries

The Librarian initiates and supports beneficial library registration

The Librarian negotiates contracts for library services, materials and equipment

Provide input into architectural planning of library facilities

The Librarian responds to customer complaints, taking action as necessary

The library is rated higher than faculty

rating the

library and

The library is rated lower than the Catering Department

Librarian

The library is rated lower than the Estates Department

The library is rated lower than the Academic Registrar's Department

The library is rated lower than the Bursar's Department

The library is rated lower than the Research Unit

The rating of the library is satisfactory

The Librarian is rated lower than Dean of Students

$3.96 \quad 1.083$

The Librarian is rated lower than the Head of Department

1.398

The Librarian is rated lower than the Academic Dean

The Librarian is rated lower than the Catering Officer

The Librarian is rated lower than the Estates Officer

The Librarian is rated lower than the Academic Registrar

The Librarian is rated lower than the Bursar

The Librarian is rated lower than the lecturer

The rating of the library is satisfactory

Librarian's

The Librarian is an officer of the university

The Librarian is a member of Senate

The Librarian is a member of Council 
In Table 1, the responses indicate the perception of satisfaction with financial management issues involving the library (mean > 4). However, observation gave a contrary view. For example, there are indications that although librarians are signatories to the library accounts, they are constrained in that their budget requests are not given priority. Often the funds released to them do not measure to the magnitude of the needs. In case of any financial crisis, library funds are easily diverted.

The opinion on the thirteen items indicates the perception that the Librarian was/is a policy maker in the university library. The opinion on only three of the items indicated. The observations and personal interview reveal that Librarians are playing a central role in the planning, development, control and management of libraries in their respective institutions, with limited interference from the top administrators.

The findings show that the respondents did not perceive the library to be rated lower than the rest of the departments in the universities. Responses are evenly distributed among those whose opinions were between neutral and disagree and these whose opinions were between neutral and agree.

The responses show that the perception that the Librarian is lower in ranking than the Bursar, Academic Registrar (but higher than the Catering Officer). This position is misleading: the University and Other Tertiary Institutions Act (2001) designates the university librarian as an officer of the university at the same level as the Academic Registrar, University Secretary and Dean of Students and that he/she is responsible to the Vice Chancellor. Since the mean scores in Table 1 were computed on a five point Likert scale, the results suggest that the Librarian's status is well recognized. However, most respondents were rather uncertain (Mean score $=3.46$ ). This implies that more needs to be done as far as the status of the Librarian is concerned.

Observations and interviews reveal adherence to this regulation among public university but not so for some private universities. The implication here is that the Librarian may not have direct access to the Vice Chancellor. In institutions where the Librarian tries to access the Vice Chancellor directly, this attempt is misunderstood and, at times, it causes conflict.

University Librarians should adopt an academic form of governance that is similar in manner and structure to other faculties. Salaries and fringe benefits should be comparable to those paid to faculty of equivalent rank. The university should recognize the importance of Librarian's continuing development within the academic community and acknowledge that such activities bring benefits to and enhance the reputation of the university, the profession and the individual Librarian. The findings on the librarians' performance are summarized in Table 2. 
Table 2: Performance of University Librarians

\begin{tabular}{|c|c|c|}
\hline Attributes of Performance & Mean & SD \\
\hline Hiring and dismissing library staff in line with your human resource policy & 3.04 & 1.33 \\
\hline Communicating optimum staffing level requirements to the Administration & 4.08 & .92 \\
\hline Supervising all library staff & 4.46 & .88 \\
\hline Initiating improvements in working conditions of the lib staff & 3.88 & 1.19 \\
\hline Identifying and supporting staff in their professional development & 4.17 & 1.02 \\
\hline Librarian handles library financial matters & 4.21 & 1.21 \\
\hline Mobilizes support for the library at local and international level & 4.04 & 1.14 \\
\hline Carries out strategic planning for the library and implements them & 4.29 & .99 \\
\hline Updates and upgrades library services & 4.46 & .93 \\
\hline Evaluates effectiveness of the library in relation to the user community & 4.17 & 1.04 \\
\hline Carries out procurement function of the library & 4.21 & 1.14 \\
\hline Prepares regular reports on current progress and future needs & 4.21 & .97 \\
\hline Cooperates with other libraries to make effective use of funds and develop services & 4 & .88 \\
\hline Directs the collection development and acquisitions including weeding & 6.22 & 10.68 \\
\hline Monitors academic and technological developments related to library work & 4.17 & 1 \\
\hline Attends meetings and workshops, local and international & 4.37 & .97 \\
\hline The Librarian is a key policy maker in a university library & 4.39 & .94 \\
\hline Keeps abreast of national, regional and international laws that affect libraries & 3.67 & 1.2 \\
\hline Initiates and supports beneficial library registration & 3.79 & 1.06 \\
\hline Provide input into architectural planning of library facilities & 3.96 & .9 \\
\hline The Librarian responds to customer complaints, taking action as necessary & 3.96 & 1.08 \\
\hline
\end{tabular}


The performance of the Librarian was examined using the above listed items. Several issues were revealed. First it can be noted from Table 2 that a Librarian has a great amount of responsibility. Second, most of the activities in the library rotates around the Librarian. Thirdly, the work of the Librarian take different forms like planning, public relations, problem solving, networking, and carrying out the technical work. It is only in the area of human resource management that respondents were not firm on a Librarian's role. This is so because in most universities, human resource issues are handled directly by a University Secretary or any other officer in charge of administration.

The contribution of status to the performance of a Librarian to her performance in the institution was considered by first of all carrying out Pearson's Bivariate Correlation. This test yielded the results as shown in Table 3.

Table 3: Pearson Correlation Coefficient for Relationship between the Status and Performance of Librarian

\begin{tabular}{lll}
\hline & & Performance \\
\hline Status of Librarian & Pearson Correlation & .673 \\
& Sig. (2-tailed) & .00 \\
& $\mathrm{~N}$ & 21 \\
\hline
\end{tabular}

Table 3 shows that there was a significant positive relationship between the status and performance of the Librarian $[\mathrm{r}=.673, \mathrm{P}<0.01]$. The inference here is that the higher the status the Librarian is accorded the better the librarian's performance. Simple regression analysis of these findings showed that the status of a librarian was a good contributor to the performance of the Librarian $[$ Beta $=.673, \mathrm{t}=3.966, \mathrm{P}<0.01]$. The Adj. $\mathrm{R}^{2}$ was .424 which meant that status contributed $42 \%$ to the Librarian's performance in the institution. Therefore university administrators should ensure that policies which are supportive of the university librarian's status are backed up by supportive frameworks in which librarians can carry out their duties.

\section{References}

Armstrong, M. (1996). Organizational behavior (6 $\left.{ }^{\text {th }} \mathrm{Ed}\right)$. London: Kogan Page Armstrong, M. (2009). Armstrong's handbook of human resource management practice. London: Kogan Page.

Barling J., Fullagar C., Marchl-Dingle J. (1988). Employment Commitment as a. Moderator of the Maternal Employment Status/Child Behavior Relationship. Developmental Psychology, 3(1), 784-802. 
D'Elia, G., Patrick, M. (1979). The Determinants of Job Satisfaction among recently graduated working Reference Librarians. New York: Wiley.

Huczynski, A. A., Buchan, A. D. (2007). Organizational behavior (6 ${ }^{\text {th }}$ Ed.). New York: Prentice Hall.

Legal Information Institute (1953). Terry v. Adams. Connell: University Law School.

Robbins, P. S., Judge, A. T. (2007). Organizational behavior (12 $2^{\text {th }}$ Ed.). New Jersey: Prentice Hall.

Rockman, C. (1985). For Human rights. ( $2^{\text {nd }}$ Ed.). Boston: Beacon Press. 